\title{
Nutritional Status of Tribal Primary School Children in Meghalaya
}

\author{
Namita Singh $^{1 *}$, Shipra Nagar ${ }^{2}$ and Ranjita Devi Takhellambam ${ }^{3}$ \\ ${ }^{1}$ Department of Food Science and Nutrition, College of Community Science, Central \\ Agricultural University, Tura, Meghalaya, India \\ ${ }^{2}$ Department of Human Development and Family Studies, College of Home Science, Central \\ Agricultural University, Tura, Meghalaya, India \\ ${ }^{3}$ Department of Food Science and Nutrition, College of Home Science, Central Agricultural \\ University, Tura, Meghalaya, India \\ *Corresponding author
}

\begin{tabular}{|c|}
\hline Keywords \\
\hline $\begin{array}{l}\text { Children, } \\
\text { Meghalaya, } \\
\text { Nutritional status, } \\
\text { Primary schools, } \\
\text { Anthropometry }\end{array}$ \\
\hline Article Info \\
\hline $\begin{array}{l}\text { Accepted: } \\
\text { 07 June } 2019 \\
\text { Available Online: } \\
\text { 10 July } 2019\end{array}$ \\
\hline
\end{tabular}

A B S T R A C T

The purpose of this study was to determine and compare the nutritional status of children aged 8-11 years attending primary school among two tribes (Khasi and Garo) of Meghalaya. Anthropometry method was used in the study. Two basic variables (height and weight) and a single derived variable (body mass index- BMI) were utilized. All the anthropometric measurements were taken following standard techniques. Twenty four hour recall method was used for dietary assessment. First degree mild malnutrition $(40.89 \%)$ and third degree severe malnutrition (3.16\%) were more prevalent in West Garo tribe children when compared to East Khasi tribe children. Varied nutritional deficiency such as riboflavin, thiamine, Vitamin C and D and iron were observed in both the tribes of Meghalaya primary children. The repeated dietary surveys in different seasons could have given more reasonable results. The data on dietary intake were based on 24 hour recall method; hence the results have all the limitations associated with the method. The results of this study, showed that the average primary school children in Meghalaya, is under nourished. Also, irrespective of gender and age, nutrient intake of West Garo tribe children is far better than the East Khasi tribe children even though the intake is less than RDA. There is an urgent need for the development of intervention programme in order to improve the nutritional status of the tribal primary school children to be employed for a longer period in order to have more change towards positivity with respect to nutritional status.

\section{Introduction}

Children form an important segment of any community. They contribute to the vital human potential and in future would impart strength to the national economy and development. Better the nutritional status of the children, higher will be their mental agility, functional capabilities and will lead to the nation's rise. There is a growing concern over the child health all over the world with rapid economic growth and social changes. The most important nutritional problem in the world today is the Protein Energy Malnutrition 
(WHO, 1983). Since poor physical growth is naturally reflected in their suboptimal mental achievement, the assessment of nutritional status of this segment of population is essential for making progress towards improving overall health of the school age children. Today's children are tomorrow's world leaders, that is why nutritional assessment in the community is essential for accurate planning and implementation of intervention program to reduce morbidity and mortality associated with under-nutrition. Anthropometrics can be sensitive indicators of health, growth and development in infants and children (Medhi et al., 2006). Anthropometry is the single most universally applicable, inexpensive and non-invasive method available to assess the size, proportion and composition of human body (WHO, 1995). According to World Health Organization (WHO), the ultimate intention of nutritional assessment is to improve human health (Beghim et al., 1998). Malnutrition which refers to an impairment of health either from a deficiency or excess or imbalance of nutrients is of public health significance among children all over the world. Adequate food and nutrition are essential for proper growth and physical development to ensure optimal work capacity, normal reproductive performance, adequate immune reactions and resistance to infections. Inadequate diet may produce severe forms of malnutrition in children such as vitamin A deficiency and iodine deficiency disorders etc. in children (Amuta and Houmsou, 2009). The Northeastern region of India is inhabited by a number of small and large tribes and in comparison to the rest of the India this area is predominated with tribal population of up to $75 \%$. Meghalaya is one of the seven sister states in the Northeastern part of India where $85.5 \%$ of the population is tribal (NCHS, 1987). Khasis, Garos and Jaintias are the three main tribes of Meghalaya (Murugkar, 2006). Despite the protection given to the tribal population by the constitution of India (1950), it remains the most backward ethnic group in India, on the three most important indicators of development i.e. health, education and income (Chakravarty et al., 2007). Today measures for better health and nutrition in tribal communities in hilly areas of India figure as one of the focus of Prime Minister's 20 point programme (Gopalan, 1992). Inadequate data available on the nutritional status of tribes of Meghalaya in general and Primary school children in particular. The study on proposed topic will help to understand the nutritional status of children and further it will help in formulation of plans and policies for the area. In this study, attempt has been made to evaluate the overall prevalence of malnutrition, assess age-sex trends as it relates to malnutrition. This study was carried out to determine and compare the nutritional status of tribal primary school children in Meghalaya.

\section{Materials and Methods}

The present study designed is a cross-sectional and was carried out during the year 20122013.

As the study was proposed to cater to the tribes of Garo and Khasi, purposive selection of two districts with the maximum population of these tribes have been done, which are East Khasi tribe and West Garo tribe. The sample size for the study had been fixed by taking prevalence of under nutrition in tribal children at 12.1 per cent and permissible level of error to 5 percent and was calculated by using formula:

$\mathrm{n}=4 \mathrm{PQ} / \mathrm{L}^{2}$

Where,

$\mathrm{P}=$ prevalence of under nutrition in tribal children 
$\mathrm{Q}=100-\mathrm{P}$

$\mathrm{L}=$ permissible level of error.

Hence, the worked out sample size comes around 675. Stratified random sampling was done to select the three developmental blocks from each district. Total 233 samples were taken from one block. Different schools were selected randomly and those schools were dropped which was not willing to be the part of overall study. So, total number of school from each developmental block varies from 27. In this way, total 1400 primary school children were selected from the two districts. However one respondent was reluctant to participate in the study. Hence the final sample size came to 1399 (702 East Khasi tribes and 697 West Garo tribes) of aged 8-11 years. Necessary approval was obtained from the school authorities prior to the commencement of the research.

\section{Assessment of nutritional status by anthropometry}

Anthropometry method as describe by Jelliffee (1966) was used in this study. Two basic variables (height and weight) and a single derived variable (body mass index) were utilized. All the anthropometric measurements were taken following standard techniques (Jelliffee, 1966). The children were weighed on a standard libra weighing machine without shoes, with arms hanging by the side, head hold straight so that the eyes were directed on the horizon. The weight had been recorded in kilograms. Accuracy of weighing machine had verified periodically by cross checking with a standard weight. The weight had been recorded to the nearest half kilogram with zero error corrected each time. For height measurement, the children were made to stand on the flat surface of the stadiometer, with feet parallel and with heels, buttocks, shoulder and back of the head touching the scale; the hands were also made to hang loosely at the sides. The head piece of the height board was then lowered to make contact with the top of the head and measurement was taken to the nearest 0.1 centimeter $(\mathrm{cm})$. Body mass index (BMI) was determined by calculation using the formula: BMI $\left(\mathrm{kg} / \mathrm{m}^{2}\right)=$ Weight $(\mathrm{kg}) /$ Height $^{2}\left(\mathrm{~m}^{2}\right)$.

\section{Clinical examination}

The important signs looked for during clinical examination are Pallor, Hair changes (sparse hair/depigmentation of hair), Eye changes (conjunctival xerosis, bitot's spots, corneal xerosis, corneal ulceration, keratomalacia) Cheilosis/angular stomatitis, Teeth changes (enamel mottling, caries, delayed eruption), Skeletal changes, Goiter, Skin changes (dry skin, flaky paint dermatosis, crazy pavement dermatosis) and Koilonychia.

\section{Dietary intake}

For dietary intake mother, who was involved in cooking was interviewed and dietary intake of the respondent was assessed in terms of quality and quantity by 24-hour recall method. Total amount of raw ingredients cooked for whole family was recorded. The nutritional profile of the household was assessed by calculation of the energy needs of the male, the female and the children in the family, in terms of those of the average man by applying appropriate coefficients to the different age and sex groups (Gopalan et al., 2010). Standardized utensils (e.g. bowls for measuring rice, vegetables, dal, milk, curd etc., spoons for measuring oil, sugar etc., dough for determining weights of chapatti) were used for measuring the approximate intake of different food items, along with this a small weighing machine was used on certain intervals in order to get more accurate results. For study subjects, dilution factor of liquid foods such as dal, tea, buttermilk etc. were 
also noted. The results of the study need to be analyzed statistically to know its significance. Appropriate statistical analysis namely per cent, mean and t-test were used to compare the data. For analysis Microsoft Excel and SPSS (Statistical packages) software programmes were mainly used.

\section{Results and Discussion}

\section{Characteristics of the children}

The primary children are not a homogenous category; they consist of different ages, belonging to different socioeconomic groups, having different health status.

The age and sex of the children is viewed with more importance to know the nutritional status of a community. Age and sex wise distribution of studied sample is presented in Table 1. Being a matrilineal society, the study population is mainly comprised of girls in both the tribes. For the East Khasi tribes, there were total of 315 boys (44.87\%) and 387 girls $(55.13 \%)$ who were in the age range of 8 to 11 years. In the West Garo tribes too, majority of the study population is comprised of 426 (61.11) girls when compared to boys (271) with being 38.9 per cent. It can be seen from the above table that majority of the East Khasi tribes children were in the age group of 11 years however for the West Garo tribe children, most of them were in the age group of 9 years.

Income is a major yardstick for judging the socio-economic status of family or community. Most of the deprivation can be traced to inadequacy of income and wealth; adequate level of income and wealth would indicate feasibility of leading a decent life and therefore, a higher level of well-being. Lower level of these could off course lead to nonfulfillment of many of the aspirations and thus correspond to a lower level of well-being.
Income earned by households would thus, apart from being an important indicator of well-being, be a proxy as well for many other aspects of well-being. A comparative analysis of the level of income earned and distribution of this among the members of the community would reveal some major aspects of the quality of life. In the present study, there exists a difference in the level of family income (Table 2). Preponderance of the East Khasi tribe $(31.33 \%)$ had a monthly family income between Rs. 5001/- to 10000/whereas West Garo tribe $(30.84 \%)$ had a monthly income between Rs.1000/- to 5000/-.

\section{Anthropometric profile}

The findings of the present study with regard to mean anthropometric profile of the respondents revealed that with respect to different age and sex, anthropometric parameters also varies in terms of weight, height and BMI (Table 3). Further irrespective of the age and sex, body weight of the respondent were varied from 19 to $32 \mathrm{~kg}$. However, Sonkar and Pandey (2011) study revealed that body weight of 150 school going children (9-12 years) of Ramabai Nagar varied between $20-25 \mathrm{~kg}$ which indicated low body weight. And the height varied from 114.81 to $136.87 \mathrm{~cm}$. The best global indicator of children's well-being is growth. Poor growth is attributable to a range of factors closely linked to overall standards of living and the ability of population to meet their basic needs, such as access to food, housing and health care.

Prevalence of malnutrition according to Gomez classification was presented in Table 4. First degree mild malnutrition $(40.89 \%)$ and third degree severe malnutrition $(3.16 \%)$ were more prevalent in West Garo tribe children when compared to East Khasi tribe children. Irrespective of the sex and age, prevalence of malnutrition is more in West Garo tribe 
children in spite of with the good nutrient intake when compared to East Khasi tribe children. The underlying reason might be frequent attack of infection/disease like malaria, jaundice due to the poor hygiene and environmental condition. The reason might be due to poverty and lower socio- economic status is the main under-lying causes of the wide prevalence of malnutrition. Thus, basically under nutrition is a problem of poverty and its roots is in economic condition, therefore economic profile of the West Garo tribe may throw some light on the contributory factor of under nutrition and the mechanism through which the respondent get the food to satisfy their nutritional and energy requirement.

\section{Clinical examination}

Clinical examination is an important indicator which reveals nutritional deficiency signs for assessment of nutritional status of communities. Table 5 depicts the nutritional deficiency of the respondents by clinical examination. Maximum percentage of Vitamin C deficiency (1.99\%) occurred in East Khasi tribe with the symptoms of spongy and bleeding gums followed by iron deficiency (giddiness) with 1.28 percent.
However the least nutrient deficiency was riboflavin $(0.14 \%)$ being angular stomatitis the symptom. Whereas in the West Garo tribe, most nutritional deficiency prevailing was Vitamin $\mathrm{C}$ with symptoms of bleeding and spongy gums, followed by thiamine (skin rashes), Vitamin D (muscle weakness) and iron (weakness) deficiency. Surprisingly that there was no Vitamin A deficiency among the respondents even though the Vitamin A intake in terms of carotene is very low when compared to RDA. The reason might be due to the food pattern in which meat becomes a staple food for the tribal in the study area which was being consumed regularly by all individuals. And there was no single case of folic acid and iodine deficiency observed in the present study.

\section{Dietary intake}

Physiological changes associated with growing stage influence food consumption pattern and dietary nutrient intakes of children. Hence, understanding the dietary intake of the children will help in improving dietary intake and thereby nutrition status. A dietary assessment is a comprehensive evaluation of a person's food intake and nutritional status of the individual.

Table.1 Distribution of the respondents according to age and sex

$\mathrm{N}=1399$

\begin{tabular}{|c|c|c|c|c|c|c|c|c|c|c|}
\hline \multirow{3}{*}{$\begin{array}{c}\text { Age } \\
\text { group } \\
\text { (yrs) }\end{array}$} & \multirow[t]{3}{*}{ Total } & \multicolumn{4}{|c|}{ East Khasi tribe $(n=702)$} & \multirow[t]{3}{*}{ Total } & \multicolumn{4}{|c|}{ West Garo tribe $(n=697)$} \\
\hline & & \multicolumn{2}{|c|}{ Boys } & \multicolumn{2}{|c|}{ Girls } & & \multicolumn{2}{|c|}{ Boys } & \multicolumn{2}{|c|}{ Girls } \\
\hline & & No. & $\%$ & No. & $\%$ & & No. & $\%$ & No. & $\%$ \\
\hline 8 & 90 & 50 & 55.56 & 40 & 44.44 & 213 & 95 & 44.60 & 118 & 55.4 \\
\hline 9 & 144 & 69 & 47.92 & 75 & 52.08 & 219 & 67 & 30.6 & 152 & 69.40 \\
\hline 10 & 125 & 48 & 38.4 & 77 & 61.6 & 159 & 56 & 35.22 & 103 & 64.8 \\
\hline 11 & 343 & 148 & 43.15 & 195 & 56.9 & 106 & 53 & 50 & 53 & 50 \\
\hline Total & 702 & 315 & 44.87 & 387 & 55.13 & 697 & 271 & 38.9 & 426 & 61.11 \\
\hline
\end{tabular}


Table.2 Distribution of households according to income

\begin{tabular}{|c|c|c|c|c|}
\hline \multirow{2}{*}{$\begin{array}{c}\text { Per capita monthly } \\
\text { income (in Rs.) }\end{array}$} & \multicolumn{2}{|c|}{ East Khasi tribe (n=702) } & \multicolumn{2}{|c|}{ West Garo tribe (n=697) } \\
\cline { 2 - 5 } & No. & $\mathbf{\%}$ & No. & $\%$ \\
\hline $1000-5000$ & 198 & 28.21 & 215 & 30.84 \\
\hline $5001-10000$ & 220 & 31.33 & 98 & 14.06 \\
\hline $10001-15000$ & 19 & 2.71 & 25 & 3.6 \\
\hline $15001-20000$ & 21 & 3.0 & 17 & 2.44 \\
\hline $20001-25000$ & 140 & 19.94 & 151 & 21.7 \\
\hline $25001-50000$ & 104 & 14.81 & 191 & 27.40 \\
\hline Total & $\mathbf{7 0 2}$ & $\mathbf{1 0 0 . 0}$ & $\mathbf{6 9 7}$ & $\mathbf{1 0 0 . 0}$ \\
\hline
\end{tabular}

Table.3 Mean anthropometric profile of primary school children of Meghalaya

$\mathrm{N}=1399$

\begin{tabular}{|c|c|c|c|c|c|}
\hline \multirow[t]{2}{*}{ District } & \multirow[t]{2}{*}{ Age } & \multirow[t]{2}{*}{ Sex } & \multicolumn{3}{|c|}{ Mean \pm SD } \\
\hline & & & Weight (kg) & Height $(\mathrm{cm})$ & BMI \\
\hline \multirow{8}{*}{$\begin{array}{l}\text { East Khasi tribe } \\
(\mathrm{n}=702)\end{array}$} & \multirow[t]{2}{*}{8 years } & Boys $(n=50)$ & $20.90 \pm 2.502$ & $118.02 \pm 6.039$ & $15.02 \pm 1.602$ \\
\hline & & Girls $(n=40)$ & $19.87 \pm 2.976$ & $114.81 \pm 6.632$ & $15.01 \pm 1.230$ \\
\hline & \multirow[t]{2}{*}{9 years } & Boys $(n=69)$ & $22.95 \pm 2.885$ & $121.70 \pm 5.507$ & $15.49 \pm 1.526$ \\
\hline & & Girls $(n=75)$ & $23.18 \pm 4.086$ & $122.13 \pm 10.072$ & $15.60 \pm 2.124$ \\
\hline & \multirow[t]{2}{*}{10 years } & Boys $(n=48)$ & $24.41 \pm 5.002$ & $124.92 \pm 6.394$ & $15.66 \pm 2.716$ \\
\hline & & Girls $(n=77)$ & $24.94 \pm 4.437$ & $124.22 \pm 6.710$ & $16.05 \pm 1.651$ \\
\hline & \multirow[t]{2}{*}{11 years } & Boys $(n=148)$ & $31.02 \pm 6.201$ & $134.13 \pm 9.835$ & $17.13 \pm 2.308$ \\
\hline & & Girls (=195) & $32.83 \pm 6.663$ & $136.87 \pm 8.809$ & $17.41 \pm 2.343$ \\
\hline \multirow{8}{*}{$\begin{array}{l}\text { West Garo tribe } \\
(\mathrm{n}=697)\end{array}$} & \multirow[t]{2}{*}{8 years } & Boys $(n=95)$ & $24.47 \pm 4.470$ & $125.76 \pm 7.119$ & $15.41 \pm 1.874$ \\
\hline & & Girls (118) & $24.96 \pm 4.763$ & $124.81 \pm 7.809$ & $15.92 \pm 2.041$ \\
\hline & \multirow[t]{2}{*}{9 years } & Boys $(n=67)$ & $25.03 \pm 3.953$ & $125.01 \pm 6.693$ & $15.91 \pm 1.207$ \\
\hline & & Girls $(n=152)$ & $25.65 \pm 5.691$ & $128.01 \pm 8.068$ & $15.54 \pm 2.280$ \\
\hline & \multirow[t]{2}{*}{10 years } & Boys $(n=56)$ & $25.13 \pm 3.671$ & $127.00 \pm 6.461$ & $15.50 \pm 1.184$ \\
\hline & & Girls $(n=103)$ & $25.95 \pm 4.766$ & $127.70 \pm 7.797$ & $15.84 \pm 2.110$ \\
\hline & \multirow[t]{2}{*}{11 years } & Boys $(n=53)$ & $24.13 \pm 5.979$ & $125.32 \pm 7.040$ & $15.19 \pm 2.901$ \\
\hline & & Girls $(n=53)$ & $27.63 \pm 6.697$ & $128.92 \pm 7.498$ & $16.47 \pm 2.819$ \\
\hline
\end{tabular}


Table.4 Nutritional status of children as per Gomez classification (Weight for age)

\begin{tabular}{|c|c|c|c|c|c|c|}
\hline \multirow[t]{2}{*}{$\begin{array}{l}\text { Malnourished } \\
\text { Grade }\end{array}$} & \multicolumn{2}{|c|}{$\begin{array}{l}\text { East Khasi Hills } \\
\qquad(n=702)\end{array}$} & \multicolumn{2}{|c|}{$\begin{array}{l}\text { West Garo Hills } \\
\qquad(\mathrm{n}=697)\end{array}$} & \multicolumn{2}{|c|}{ Total $(\mathrm{N}=1399)$} \\
\hline & No. & Percentage & No. & Percentage & No. & Percentage \\
\hline $\begin{array}{l}>89 \\
\text { Normal }\end{array}$ & 303 & 43.16 & 279 & 40.03 & 582 & 41.60 \\
\hline $\begin{array}{l}>74 \text { to } \leq 89 \\
1^{\text {st }} \text { degree } \\
\text { mild } \\
\text { malnutrition }\end{array}$ & 250 & 35.61 & 286 & 40.89 & 536 & 38.31 \\
\hline $\begin{array}{l}\leq 74 \text { to } \geq 60 \\
2^{\text {nd }} \text { degree } \\
\text { moderate } \\
\text { malnutrition }\end{array}$ & 139 & 19.80 & 110 & 15.78 & 249 & 17.80 \\
\hline $\begin{array}{l}<60 \\
3^{\text {rd }} \text { degree } \\
\text { severe } \\
\text { malnutrition }\end{array}$ & 10 & 1.42 & 22 & 3.16 & 32 & 2.30 \\
\hline Total & 702 & 100.0 & 697 & 100.0 & 1399 & 100.0 \\
\hline
\end{tabular}

Table.5 Nutritional deficiency of the respondents by clinical examination

$\mathrm{N}=1399$

\begin{tabular}{|l|c|c|c|c|}
\hline \multirow{2}{*}{$\begin{array}{l}\text { Nutrient } \\
\text { deficiency }\end{array}$} & \multicolumn{2}{|c|}{ East Khasi tribe $(\mathbf{n = 7 0 2})$} & \multicolumn{2}{c|}{ West Garo tribe (n= 697) } \\
\cline { 2 - 5 } & Number & Percentage & Number & Percentage \\
\hline Riboflavin & 1 & 0.14 & - & - \\
\hline Thiamine & - & - & 2 & 0.28 \\
\hline Vitamin C & 14 & 1.99 & 5 & 0.71 \\
\hline Vitamin D & - & - & 2 & 0.28 \\
\hline Iron & 9 & 1.28 & 2 & 0.28 \\
\hline
\end{tabular}


Table.6 Nutrient intake comparison of girls among the two tribes of Meghalaya

\begin{tabular}{|c|c|c|c|c|c|}
\hline \multirow[t]{2}{*}{ Nutrient (Mean \pm SD) } & \multirow[t]{2}{*}{ Districts } & \multicolumn{4}{|l|}{ Age (Years) } \\
\hline & & 8 & 9 & 10 & 11 \\
\hline \multirow[t]{3}{*}{ Energy (kcal/day) } & EKT $(n=386)$ & $\begin{array}{l}1705 \pm 572.9 \\
(1950)\end{array}$ & $\begin{array}{l}1495 \pm 595.05 \\
(1950)\end{array}$ & $\begin{array}{l}1479 \pm 567.74 \\
(1970)\end{array}$ & $\begin{array}{l}1335 \pm 717.59 \\
(1970)\end{array}$ \\
\hline & WGT $(n=426)$ & $1381 \pm 567.28$ & $1547 \pm 651.98$ & $1558 \pm 670.95$ & $1365 \pm 584.17$ \\
\hline & t-value & $0.002 * *$ & $0.561^{\mathrm{NS}}$ & $0.402^{\mathrm{NS}}$ & $0.780^{\mathrm{NS}}$ \\
\hline \multirow[t]{3}{*}{ Protein (g/day) } & EKT & $\begin{array}{l}53.78 \pm 34.44 \\
(41)\end{array}$ & $\begin{array}{l}53.14 \pm 31.99 \\
(41)\end{array}$ & $\begin{array}{l}56.46 \pm 34.95 \\
(57)\end{array}$ & $\begin{array}{l}57.68 \pm 36.52 \\
(57)\end{array}$ \\
\hline & WGT & $51.39 \pm 33.21$ & $57.99 \pm 34.46$ & $58.12 \pm 35.82$ & $44.59 \pm 30.07$ \\
\hline & t-value & $0.699^{\mathrm{NS}}$ & $0.308^{\mathrm{NS}}$ & $0.755^{\mathrm{NS}}$ & $0.017^{*}$ \\
\hline \multirow[t]{3}{*}{ Fat (g/day) } & EKT & $\begin{array}{l}6.88 \pm 6.14 \\
(25)\end{array}$ & $\begin{array}{l}9.50 \pm 11.02 \\
(25)\end{array}$ & $\begin{array}{l}9.62 \pm 10.97 \\
(25)\end{array}$ & $\begin{array}{l}16.20 \pm 13.47 \\
(22)\end{array}$ \\
\hline & WGT & $9.79 \pm 10.60$ & $9.29 \pm 11.08$ & $11.17 \pm 10.87$ & $10.70 \pm 11.36$ \\
\hline & t-value & $0.106^{\mathrm{NS}}$ & $0.894^{\mathrm{NS}}$ & $0.345^{\mathrm{NS}}$ & $0.007 * *$ \\
\hline \multirow[t]{3}{*}{ Calcium (mg/day) } & $\mathrm{EKT}$ & $\begin{array}{l}501.61 \pm 226.26 \\
(400)\end{array}$ & $\begin{array}{l}635.46 \pm 378.56 \\
(400)\end{array}$ & $\begin{array}{l}610.28 \pm 391.15 \\
(600)\end{array}$ & $\begin{array}{l}910.61 \pm 608.82 \\
(600)\end{array}$ \\
\hline & WGT & $612.34 \pm 336.81$ & $656.70 \pm 399.66$ & $765.93 \pm 512.16$ & $684.66 \pm 385.58$ \\
\hline & t-value & $0.058^{\mathrm{NS}}$ & $0.702^{\mathrm{NS}}$ & $0.027 *$ & $0.011 *$ \\
\hline \multirow[t]{3}{*}{ Iron (g/day) } & $\mathrm{EKT}$ & $\begin{array}{l}8.03 \pm 4.72 \\
(26)\end{array}$ & $\begin{array}{l}8.42 \pm 5.28 \\
(26)\end{array}$ & $\begin{array}{l}7.65 \pm 5.16 \\
(19)\end{array}$ & $\begin{array}{l}8.17 \pm 5.39 \\
(19)\end{array}$ \\
\hline & WGT & $6.84 \pm 3.19$ & $7.85 \pm 4.07$ & $7.67 \pm 3.91$ & $7.72 \pm 2.85$ \\
\hline & t-value & $0.078^{\mathrm{NS}}$ & $0.375^{\mathrm{NS}}$ & $0.978^{\mathrm{NS}}$ & $0.561^{\mathrm{NS}}$ \\
\hline \multirow[t]{3}{*}{ Ascorbic acid (mg/day) } & EKT & $\begin{array}{l}44.19 \pm 28.72 \\
(40)\end{array}$ & $\begin{array}{l}36.71 \pm 28.94 \\
(40)\end{array}$ & $\begin{array}{l}30.53 \pm 22.91 \\
(40)\end{array}$ & $\begin{array}{l}38.59 \pm 28.78 \\
(40)\end{array}$ \\
\hline & WGT & $31.42 \pm 24.23$ & $32.13 \pm 25.77$ & $35.22 \pm 24.78$ & $49.23 \pm 29.88$ \\
\hline & t-value & $0.007 * *$ & $0.228^{\mathrm{NS}}$ & $0.194^{\mathrm{NS}}$ & $0.019 *$ \\
\hline \multirow[t]{3}{*}{ Carotene ( $\mu \mathrm{g} / \mathrm{day})$} & EKT & $\begin{array}{l}659.01 \pm 324.20 \\
(2400)\end{array}$ & $\begin{array}{l}899.74 \pm 638.10 \\
(2400)\end{array}$ & $\begin{array}{l}692.30 \pm 439.00 \\
(2400)\end{array}$ & $\begin{array}{l}988.15 \pm 825.82 \\
(2400)\end{array}$ \\
\hline & WGT & $749.71 \pm 525.58$ & $895.33 \pm 649.76$ & $792.36 \pm 454.28$ & $791.01 \pm 779.37$ \\
\hline & t-value & $0.312^{\mathrm{NS}}$ & $0.961^{\mathrm{NS}}$ & $0.138^{\mathrm{NS}}$ & $0.120^{\mathrm{NS}}$ \\
\hline
\end{tabular}

Note: Figures in parenthesis indicates estimated RDA of corresponding nutrients and the age, respectively. EKT-East Khasi tribe, WGT-West Garo tribe. ${ }^{*} \mathrm{p} \leq 0.05,{ }^{*} \mathrm{p} \leq 0.01$, NS-Not significant 
Table.7 Nutrient intake comparison of boys among the two tribes of Meghalaya

\begin{tabular}{|c|c|c|c|c|c|}
\hline \multirow[t]{2}{*}{ Nutrient (Mean \pm SD) } & \multirow[t]{2}{*}{ Districts } & \multicolumn{4}{|c|}{ Age (Years) } \\
\hline & & 8 & 9 & 10 & 11 \\
\hline \multirow[t]{3}{*}{ Energy (kcal/day) } & EKT $(n=316)$ & $\begin{array}{c}1559 \pm 375.91 \\
(1950)\end{array}$ & $\begin{array}{c}1522 \pm 544.62 \\
(1950)\end{array}$ & $\begin{array}{c}1421 \pm 726.00 \\
(2190)\end{array}$ & $\begin{array}{c}1295 \pm 701.19 \\
(2190)\end{array}$ \\
\hline & WGT $(n=271)$ & $1548 \pm 729.19$ & $1091 \pm 535.77$ & $1142 \pm 580.19$ & $1366 \pm 627.37$ \\
\hline & t-value & $0.925^{\mathrm{NS}}$ & $0.000 * *$ & $0.032 *$ & $0.514^{\mathrm{NS}}$ \\
\hline \multirow[t]{3}{*}{ Protein (g/day) } & EKT & $\begin{array}{c}45.27 \pm 18.67 \\
(41)\end{array}$ & $\begin{array}{c}56.72 \pm 32.22 \\
(41)\end{array}$ & $\begin{array}{c}52.80 \pm 36.83 \\
(54)\end{array}$ & $\begin{array}{c}61.72 \pm 36.92 \\
(54)\end{array}$ \\
\hline & WGT & $59.26 \pm 37.04$ & $51.32 \pm 35.18$ & $46.81 \pm 35.27$ & $54.32 \pm 31.36$ \\
\hline & t-value & $0.013^{*}$ & $0.351^{\mathrm{NS}}$ & $0.399^{\mathrm{NS}}$ & $0.195^{\mathrm{NS}}$ \\
\hline \multirow[t]{3}{*}{ Fat (g/day) } & EKT & $\begin{array}{l}5.82 \pm 4.58 \\
\quad(25)\end{array}$ & $\begin{array}{c}8.32 \pm 10.23 \\
(25)\end{array}$ & $\begin{array}{c}12.98 \pm 13.98 \\
(22)\end{array}$ & $\begin{array}{c}16.44 \pm 13.35 \\
(22)\end{array}$ \\
\hline & WGT & $11.68 \pm 12.14$ & $17.48 \pm 13.13$ & $21.35 \pm 17.55$ & $15.92 \pm 11.97$ \\
\hline & t-value & $0.001 * *$ & $0.000 * *$ & $0.009 * *$ & $0.804^{\mathrm{NS}}$ \\
\hline \multirow[t]{3}{*}{ Calcium (mg/day) } & EKT & $\begin{array}{c}451.21 \pm 218.31 \\
(400)\end{array}$ & $\begin{array}{c}568.84 \pm 322.38 \\
(400)\end{array}$ & $\begin{array}{c}735.39 \pm 526.08 \\
(600)\end{array}$ & $\begin{array}{c}882.23 \pm 473.56 \\
(600)\end{array}$ \\
\hline & WGT & $554.57 \pm 56.89$ & $892.75 \pm 487.20$ & $1080.6 \pm 720.21$ & $808.32 \pm 402.01$ \\
\hline & t-value & $0.000 * *$ & $0.000 * *$ & $0.007 * *$ & $0.312^{\mathrm{NS}}$ \\
\hline \multirow[t]{3}{*}{ Iron (g/day) } & EKT & $\begin{array}{l}5.98 \pm 3.09 \\
(26)\end{array}$ & $\begin{array}{l}7.72 \pm 4.20 \\
(26)\end{array}$ & $\begin{array}{l}8.27 \pm 5.44 \\
(34)\end{array}$ & $\begin{array}{l}9.08 \pm 5.65 \\
(34)\end{array}$ \\
\hline & WGT & $8.07 \pm 4.36$ & $7.34 \pm 4.28$ & $7.73 \pm 4.12$ & $8.84 \pm 5.04$ \\
\hline & t-value & $0.003 * *$ & $0.605^{\mathrm{NS}}$ & $0.569^{\mathrm{NS}}$ & $0.787^{\mathrm{NS}}$ \\
\hline \multirow[t]{3}{*}{ Ascorbic acid (mg/day) } & EKT & $\begin{array}{c}32.47 \pm 22.85 \\
(40)\end{array}$ & $\begin{array}{c}33.90 \pm 26.97 \\
(40)\end{array}$ & $\begin{array}{c}33.74 \pm 24.58 \\
(40)\end{array}$ & $\begin{array}{c}36.63 \pm 26.95 \\
(40)\end{array}$ \\
\hline & WGT & $34.17 \pm 27.13$ & $40.80 \pm 23.41$ & $42.07 \pm 29.26$ & $39.55 \pm 33.32$ \\
\hline & t-value & $0.706^{\mathrm{NS}}$ & $0.112^{\mathrm{NS}}$ & $0.123^{\mathrm{NS}}$ & $0.527^{\mathrm{NS}}$ \\
\hline \multirow[t]{3}{*}{ Carotene ( $\mu \mathrm{g} / \mathrm{day})$} & EKT & $\begin{array}{c}589.77 \pm 327.66 \\
(2400)\end{array}$ & $\begin{array}{c}822.83 \pm 699.71 \\
(2400)\end{array}$ & $\begin{array}{c}747.94 \pm 459.39 \\
(2400)\end{array}$ & $\begin{array}{c}1140.5 \pm 879.92 \\
(2400)\end{array}$ \\
\hline & WGT & $845.61 \pm 548.89$ & $988.31 \pm 775.91$ & $1344.50 \pm 1296.77$ & $1060.70 \pm 860.14$ \\
\hline & t-value & $0.003 * *$ & $0.193^{\mathrm{NS}}$ & $0.003^{* *}$ & $0.569^{\mathrm{NS}}$ \\
\hline
\end{tabular}

Note: Figures in parenthesis indicates estimated RDA of corresponding nutrients and the age, respectively. EKT-East Khasi tribe, WGT-West Garo tribe. ${ }^{*} \mathrm{p} \leq 0.05,{ }^{* *} \mathrm{p} \leq 0.01$, NS-Not significant 


\section{Int.J.Curr.Microbiol.App.Sci (2019) 8(7): 668-681}

Fig.1 Nutrient intake comparison of the Primary girls with RDA children
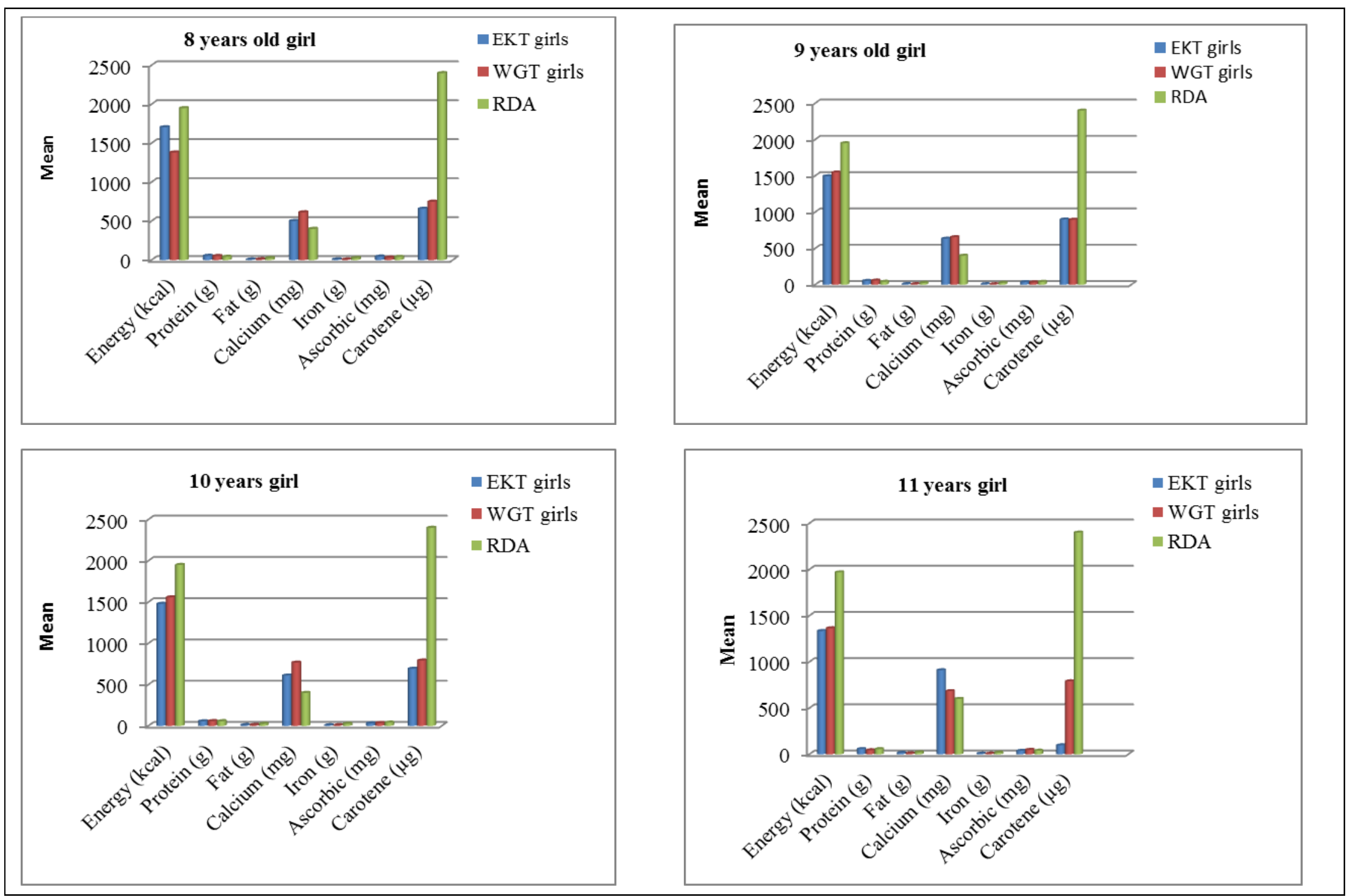
Fig.2 Nutrient intake comparison of the Primary boys with RDA
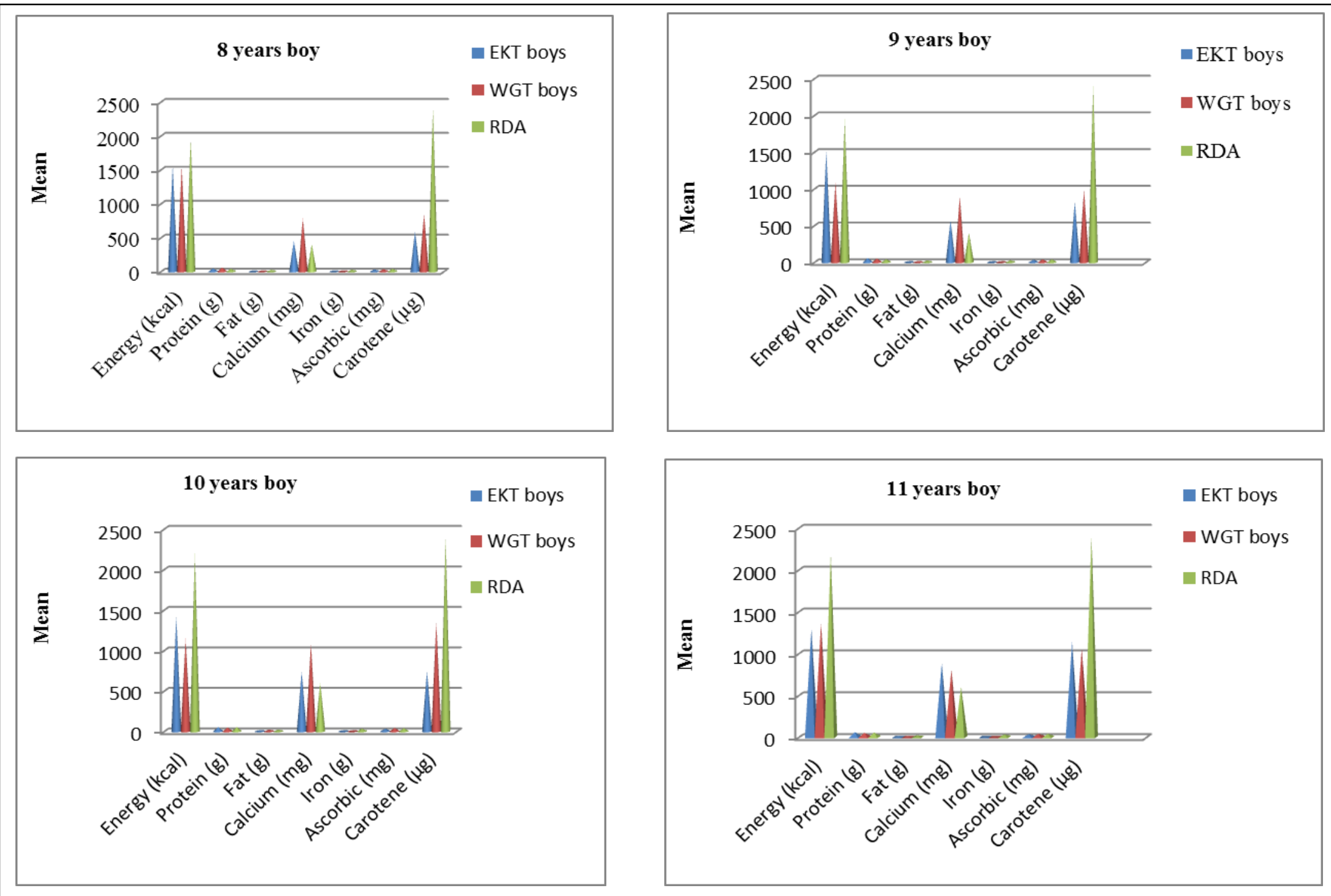
The present study revealed that mean intake of nutrients (Table 6) by the girls respondents of both tribes in terms of energy, fat, calcium, iron, ascorbic acid and carotene were comparatively lower in comparison with reference standards of respective age group of RDA (Fig. 1). Kasturiba et al., (2007) and Prakash et al., (2010) also reported that the mean intake of fat, iron and $\beta$-carotene of school children of age group of 8-12 years was less than the RDA.

In the present study, the reason for being recorded lower intake of nutrients is due to the non-inclusion of milk and milk product and fat in their meal pattern as tribal people prefer to have a bland diet. Similar findings was reported by Singh (2010) which indicated that the intake of milk and milk products and fat was less in the Tura. In addition, Sonkar and Pandey (2011) also reported that nutrient intake such as energy, fat, iron, calcium and vitamin C of 150 school going children (9-12 years) of Ramabai Naga, Kanpur was found to be lesser when compared to RDA. Whereas protein was comparatively more or similar with reference to RDA.

Among the boy's respondent (Table 7), the mean intake of nutrient such as energy, fat, iron, ascorbic acid and carotene were comparatively lower than RDA (Fig. 2). However, the mean fat and ascorbic acid intake is far better in the West Garo tribe when compared to East Khasi tribe. The mean protein and calcium intake is more in both tribes when compared to RDA.

Hence considering in both the gender and age (Table 6 and 7), it can be stated that the nutrient intake of West Garo tribe children is far better than the East Khasi tribe children even though the intake is less than RDA. On the contrary, Rynjah and co-workers (2009) reported that the typical Khasi meal had a balance with rice in semi and unpolished form, fermented soyabean, vegetables, such as cauliflower leaves, potatoes nonconventional seasonal fruits such as peaches, passion fruit, plums and wild berries. Nonvegetarian foods such as meat, fish and oils such as mustard and refined oils had a protective role. However, in the present study the availability of food and nutrients among the respondents in a study area is conditioned largely by various economic situations. But in the present study economic condition of East Khasi tribe is superior than West Garo tribe. So another reason for the lower intake of nutrient among the children might be due to negligence and lack of awareness of the respondents parents especially mother who is responsible in the food preparation in terms of variety in the diet, adequacy with proper meal pattern. Sometimes ignorance on the part of parents to know the requirement of children, quantitatively or qualitatively may lead to reduce in dietary intake of children. When the child is in a hurry to go to school, he may skip breakfast or may not carry proper lunch to school or may become too tired after school activities and sleep off without taking night meals. Emotional disturbances at school due to poor academic performance or problems with siblings at home may reflect on the consumption of food (Shrilakshmi, 2014). On the contrary, Singh (2010) reported that female population of "Garo" tribe of Meghalaya has very poor nutritional knowledge in terms of their food pattern and practices.

From the results of this study, it is clear that irrespective of the sex and age, prevalence of malnutrition is more in West Garo tribe children in spite of with the good nutrient intake when compared to East Khasi tribe children in which first degree mild malnutrition $(40.89 \%)$ and third degree severe malnutrition $(3.16 \%)$ were more prevalent in West Garo tribe children. Varied nutritional deficiency such as riboflavin, thiamine, 
Vitamin C and D and iron were observed in both the tribes of Meghalaya primary children. However, interesting finding in the present study is that there was no Vitamin A deficiency among the respondents even though the Vitamin A intake in terms of carotene is very low when compared to RDA. And there was no single case of folic acid and iodine deficiency observed in the present study.

These children do not realize their full potential for growth. Urgent steps should therefore be taken to meet nutritional needs of the children; this can be achieved by educating mothers and women groups on the utilization and processing techniques of available and cheaper sources of protein. Also, the standard of living should be improved as this is the only means by which the primary cause of malnutrition could be tackled.

\section{Acknowledgement}

This paper is a part of external funded research project. This was funded by Indian Council of Medical Research.

\section{References}

Amuta, E.U., and Houmsou, R.S. 2009. Assessment of Nutritional Status of School Children in Makurdi, Benue State. Pakistan Journal of Nutrition, 8(5), 691-694. DOI:10.3923/PJN.2009. 691.694

Beghim, I., Cap, M.R. and Dujardin, B. 1998. A Guide to Nutritional Assessment, World Health Organization, Geneva.

Chakravarty, S., Shukla, G. and Suresh, C.P. 2007. Tribal welfare and Development in India: Past, present and strategies with special reference to agriculture and forestry. Kurukshetra. A Journal of Rural Development, 56(1), 33-39.
Gopalan, C. 1992. Nutrition challenge for Asia. Progress in Food and Nutrition Science. 16, pp.51-84.

Gopalan, C., Sastri, B.V.R. and Balasubramanian, S.C. 2010. Nutritive value of Indian foods, National Institute of Nutrition, ICMR, Hyderabad.

Jellife, D.B. 1966. The assessment of the nutritional status of the community. WHO. Monograph Series (53). Geneva.

Kasturiba, B., Naik, R. K. and Basarkar, P.W. 2007. Adequacy of related nutrients and vitamin A status of school children. The Indian Journal of Nutrition and Dietetics, 44, 154-159.

Medhi, G.K., Barua, A. and Mahanta, J. 2006. Growth and nutritional status of school age children (6-14) years of tea garden worker of Assam. Journal of Human Ecology, 19(2), 83-85 https://doi.org/10.1080/09709274.2006. 11905860

Murugkar, D.A. "Interventions Using Wild Edibles to Improve the Nutritional Status of Khasi tribal Women", available at http://www.krepublishers.com/06Special\%20Volume-Journal/JHE-00Special\%20Volumes/JHE-14-Eco-CulNut-Hlth-Dis-Web/JHE-SI-14-11-083088-Agrahar-Murugkar-D/JHE-SI-1411-083-088-Agrahar-Murugkar-D-

Text.pdf (accessed 13 January 2009)

National Centre for Health Statistics 1987. Anthropometric and prevalence of overweight, US 1976-1980. Vital and Health statistics, Series 11, No 238, (DHHS Pub.No PHS, 87-1688).

Prakash, D.J., Dachana, K.B. and Prakash, J. 2010. Nutritional status and dietary intake of children from urban and rural schools providing mid-day meal. The Indian Journal of Nutrition and Dietetics, 47(9), 394-403.

Rynjah, A., Anuradha, V. and Thilagamani, S. 2009. Nutritional status of tobacco users 
among the Khasi tribes in Meghalaya. The Indian Journal of Nutrition and Dietetics, 46(9), 357-363.

Singh, N. 2010. Nutritional knowledge and practices among "Garo" tribe of Meghalaya, Intra Mural Research Project report, Central Agricultural University.

Sonkar, S. and Pandey, A. 2011. Nutritional assessment and life style of primary school children in Ramabai Nagar. Asian Journal of Home Science, 6(2), 265-268.
Srilakshmi, B. 2014. Nutritional and food requirements for school children-6 to 12 years. Dietetics. New Age International Publishers. New Delhi, India, p 97

World Health Organisation 1983. Measuring change in Nutritional status: guidelines for assessing the nutritional Impact of supplementary feeding programs for vulnerable groups, WHO Geneva, 9.

World Health Organization 1995. Physical Status: The Use and Interpretation of Anthropometry Geneva Technical Report Series, 854.

\section{How to cite this article:}

Namita Singh, Shipra Nagar and Ranjita Devi Takhellambam. 2019. Nutritional Status of Tribal Primary School Children in Meghalaya. Int.J.Curr.Microbiol.App.Sci. 8(07): 668-681. doi: https://doi.org/10.20546/ijcmas.2019.807.083 